\title{
Toxic Alkaloid Concentrations in Delphinium nuttallianum, Delphinium andersonii, and Delphinium geyeri in the Intermountain Region
}

\author{
Dale R. Gardner ${ }^{1}$ and James A. Pfister ${ }^{2}$ \\ Authors are ${ }^{1}$ Research Chemist and ${ }^{2}$ Rangeland Scientist, USDA-ARS Poisonous Plant Research Laboratory, 1150 E. 1400 N., Logan, UT 84341.
}

\begin{abstract}
Low larkspurs (Delphinium nuttalliunum Pritz., Delphinium andersonii Gray) and plains larkspur (Delphinium geyeri Greene) often poison cattle grazing on western North American rangelands. The dominant toxic alkaloid in larkspur is methyllycaconitine (MLA); other very toxic alkaloids in low and plains larkspurs are nudicauline and geyerline. Toxic alkaloid concentrations in larkspur near or above $3 \mathrm{mg} \cdot \mathrm{g}^{-1}$ present significant risk to grazing cattle. D. nuttallianum from Utah and Colorado, D. andersonii from northern Arizona, and plains larkspur (D. geyeri) from Wyoming were collected for analysis. Concentrations of MLA in $D$. nuttallianum ranged from 0.8 to $4.5 \mathrm{mg} \cdot \mathrm{g}^{-1}$ in Utah and Colorado; total toxic alkaloid concentrations were often above $3 \mathrm{mg} \cdot \mathrm{g}^{-1}$. D. nuttallianum differed $(P=0.09)$ in MLA concentration between locations but not phenological stages $(P=0.41)$. Concentrations of nudicauline ranged from 0.7 to $4 \mathrm{mg} \cdot \mathrm{g}^{-1}$ in $D$. nuttallianum and were different $(P=0.01)$ between locations and phenological stages $(P=0.004)$. D. andersonii was consistently toxic because the total toxic alkaloid concentration fluctuated from 3 to $6 \mathrm{mg} \cdot \mathrm{g}^{-1}$ over the growing season. The concentration of geyerline in D. andersonii was equal to or greater than MLA at each phenological stage, thus adding to the toxicity. The concentration of toxic alkaloids in D. geyeri was typically highest $\left(2-4 \mathrm{mg} \cdot \mathrm{g}^{-1}\right)$ in immature plants, although toxic alkaloid concentrations in plants during the pod stage of growth sometimes increased. Only trace amounts of nudicauline were found in D. geyeri, as most of the alkaloid fraction was other $\mathrm{N}$-(methylsuccinimido) anthranoyllycoctonine (MSAL) alkaloids. Total alkaloid concentration (MSAL and non-MSAL alkaloids) in D. geyeri sometimes exceeded $15 \mathrm{mg} \cdot \mathrm{g}^{-1}$. Concentrations of toxic alkaloids in D. nuttalliunum, D. andersonii, and D. geyeri often did not significantly decline during the growing season as typically found in tall larkspurs. Thus, risk to grazing cattle may remain high until these plants are dormant.
\end{abstract}

\section{Resumen}

El "Low larkspurs" (Delphinium nuttalliunum Pritz., Delphinium andersonii Gray) y "Plains larkspur" (Delphinium geyeri Greene) a menudo envenenan el ganado que apacienta los pastizales del oeste de Norte América. El alcaloide tóxico dominante en "Larkspur" es metilicacontina (MLA); otros alcaloides muy tóxicos presentes en "Low larkspurs" y "Plains larkspur" son nudicaulina y geierlina. En "Larkspur", las concentraciones de alcaloides tóxicos cercanas o superiores a $3 \mathrm{mg} \cdot \mathrm{g}^{-1}$ presentan un riesgo significativo para el ganado en apacentamiento. D. nuttallianum de Utah y Colorado, D. andersonii del norte de Arizona y "Plains larkspur" (D. geyeri) de Wyoming se colectaron para análisis. Las concentraciones de MLA en D. nuttallianum fluctuaron de 0.8 a $4.5 \mathrm{mg} \cdot \mathrm{g}^{-1}$ en Utah y Colorado; las concentraciones totales de alcaloides tóxicos a menudo fueron superiores a $3 \mathrm{mg} \cdot \mathrm{g}^{-1}$. La concentración de MLA en $D$. nuttallianum difirió $(P=0.09)$ entre localidades, pero no entre estados fenológicos $(P=0.41)$. Las concentraciones de nudicaulina variaron de $0.7 \mathrm{a} 4 \mathrm{mg} \cdot \mathrm{g}^{-1}$ en $D$. nuttallianum, y fueron diferentes $(P=0.01)$ entre localidades y etapas fenológicas $(P=0.004)$. El $D$. andersonii fue consistentemente tóxico porque la concentración total de alcaloides fluctuó de 3 a $6 \mathrm{mg} \cdot \mathrm{g}^{-1}$ a través de la estación de crecimiento. La concentración de geierlina en $D$. andersonii fue igual o superior a la de MLA en cada uno de las etapas fenológicas, aumentando así la toxicidad. La concentración de los alcaloides tóxicos en D. geyeri $\left(2 \mathrm{a} 4 \mathrm{mg} \cdot \mathrm{g}^{-1}\right)$ fue típicamente mayor en plantas jóvenes, aunque las concentraciones de alcaloides tóxicos en la etapa de formación de vaina algunas veces se incrementaron. En D. geyeri se encontraron solo cantidades traza de nudicaulina, la mayoría de la fracción de alcaloides la conformaron otros alcaloides $\mathrm{N}$-(methylsuccinimido) anthranoyllycoctonine (MSAL). La concentración total de alcaloides (alcaloides MSAL y no-MSAL) en D. geyeri algunas veces excedió $\operatorname{los} 15 \mathrm{mg} \cdot \mathrm{g}^{-1}$. Las concentraciones de alcaloides tóxicos en D. nuttalliunum, D. andersonii, y D. geyeri a menudo no disminuyen significativamente durante la estación de crecimiento, como ocurre típicamente en los "Tall larkspurs." Así, el riesgo para el ganado en apacentamiento puede permanecer alto hasta que estas plantas están en dormancia.

Key Words: diterpenoid alkaloids, cattle, larkspur, poisonous plants, methyllycaconitine

\section{INTRODUCTION}

Correspondence: Dr Dale Gardner, USDA-ARS Poisonous Plant Research Laboratory, 1150 E. 1400 N., Logan, UT 84341. Email: Dale.Gardner@ars.usda.gov

Manuscript received 9 November 2006; manuscript accepted 1 April 2007.
Low larkspurs (Delphinium nuttalliunum Pritz., Delphinium andersonii Gray) and plains larkspur (Delphinium geyeri Greene) are toxic plants that often fatally poison cattle on western North American rangelands (Majak 1993; Pfister et al. 2003). Larkspur species contain norditerpenoid alkaloids 
Table 1. Collection sites and dates for low larkspurs (Delphinium nuttallianum and D. andersonii) and plains larkspur (D. geyeri).

\begin{tabular}{lllc}
\hline Species & \multicolumn{1}{c}{ General location } & \multicolumn{1}{c}{ GPS coordinates } & Collection dates \\
\hline D. andersonii & Arizona Strip, Arizona & $36^{\circ} 22.61 \mathrm{~N}, 113^{\circ} 2.17 \mathrm{~W}$ & 1997 \\
D. nuttallianum & Box Elder County, Utah & $41^{\circ} 29.80 \mathrm{~N}, 113^{\circ} 39.00 \mathrm{~W}$ & 1996,1997 \\
D. nuttallianum & Bear Lake, Utah & $41^{\circ} 50.50 \mathrm{~N}, 111^{\circ} 17.61 \mathrm{~W}$ & $1995,1996,1997$ \\
D. nuttallianum & Yampa, Colorado & $40^{\circ} 12.03 \mathrm{~N}, 107^{\circ} 04.64 \mathrm{~W}$ & $1995,1996,1997$ \\
D. nuttallianum & Price, Utah & $41^{\circ} 45.41 \mathrm{~N}, 111^{\circ} 48.42 \mathrm{~W}$ & 1996,1997 \\
D. geyeri & Larimer County, Colorado & $40^{\circ} 58.86 \mathrm{~N}, 105^{\circ} 10.55 \mathrm{~W}$ & 1996 \\
D. geyeri & Cheyenne, Wyoming & $41^{\circ} 5.40 \mathrm{~N}, 105^{\circ} 0.31 \mathrm{~W}$ & 1996,1997 \\
D. geyeri & Laramie, Wyoming & $41^{\circ} 17.19 \mathrm{~N}, 105^{\circ} 43.83 \mathrm{~W}$ & 1998,1999 \\
\hline
\end{tabular}

(Manners et al. 1995, 1998), and the dominant toxic alkaloid in low larkspurs and plains larkspur is methyllycaconitine (MLA; Manners et al. 1995; Gardner et al. 2000). The alkaloids nudicauline and geyerline are also very toxic to cattle (Manners et al. 1995; Gardner et al. 2000). These alkaloids are toxic because they are esterified with $\mathrm{N}$-(methylsuccinimido) anthranoyllycoctonine (MSAL) at the C-18 alcohol. Larkspurs may contain other non-MSAL alkaloids (e.g., deltaline) in relatively high concentrations, but the MSAL-type alkaloids are an order of magnitude more toxic than are alkaloids in the other groups (Manners et al. 1995; Gardner et al. 2000).

Low larkspurs typically initiate growth before other forage species during the spring. Low larkspur occurrence is often cyclic, as plant density and seasonal longevity are influenced by precipitation patterns and temperature (Majak and Engelsjord 1988; Saavedra et al. 2003). The presence of larkspur may dictate summer grazing management as producers attempt to reduce livestock losses (Pfister et al. 1997). A long-established management practice is to defer grazing until larkspur pods have shattered and toxicity is presumed to be low (Marsh et al. 1916; Pfister and Gardner 1999).

Information on toxic alkaloid concentrations is critical in making management decisions about grazing rangelands, and to determine the risk of poisoning. In this study we provide information on toxic alkaloid concentrations of D. nuttalliunum, D. andersonii, and D. geyeri at several western US locations.

\section{METHODS}

Low larkspur plants were collected at sites in Utah, Colorado, and Arizona during 1995, 1996, and 1997 (Table 1). Plains larkspur (D. geyeri) was collected near Laramie and Cheyenne, Wyoming, during 1996-1999. Sites were selected on the basis of 2 criteria: first, the sites had persistent populations of larkspur plants, and, second, there were anecdotal reports of toxicity to cattle from larkspur in the general area.

Ten to 20 plants were randomly harvested at each site. Collections coincided as much as possible with the flower and pod stages of growth, as these are typically most problematic. Samples were placed on ice, then later frozen at $-20^{\circ} \mathrm{C}$. Frozen samples were freeze-dried and ground to pass a $1-\mathrm{mm}$ screen. Samples were weighed fresh and after drying to determine percent of dry matter. Low larkspurs were analyzed for diterpenoid alkaloids by electrospray mass spectroscopy
(Gardner et al. 1999). All results are shown on a dry-weight basis. Results for low larkspur (D. nuttallianum and D. andersonii) are presented as concentrations of MLA, nudicauline or geyerline, other MSAL alkaloids, and total toxic alkaloids. Plains larkspur alkaloid concentration was determined using Fourier transform infrared spectroscopy (Gardner et al. 1997). Preliminary screening of plains larkspur samples found that the toxic alkaloid composition was comprised primarily of MLA and geyerline. Other MSAL alkaloids (i.e., nudicauline, 14-deacetylnudicauline, bearline, 14-acetylbearline, and 16-deacetylgeyerline) were either absent or present only in trace amounts. Geyerline and MLA have similar toxicity; thus, their combined concentration in D. geyeri is reported as total MSAL alkaloid concentration. Total alkaloid concentration (MSAL and non-MSAL alkaloids) is also reported for D. geyeri.

\section{Statistical Analysis}

A mixed-model analysis of variance was used for data analysis of alkaloid concentration in low larkspurs using SAS (SAS Institute 2002). Year was considered a source of variability; thus, year was a random effects factor. The model used was location, year within location, phenology, phenology $\times$ location, and phenology $\times$ year within location. Year within location was the error term for location, and residual error was used to test the phenology terms. Only descriptive statistics are shown for plains larkspur because years and locations were confounded.

\section{RESULTS}

\section{D. nuttallianum Alkaloid Concentration}

D. nuttallianum differed $(P=0.09)$ in MLA concentration between locations but not phenological stages $(P=0.41)$. Concentrations of nudicauline were different $(P=0.01)$ between locations and phenological stages $(P=0.004)$; the interaction was also significant $(P=0.04$; Fig. 1$)$. Total MSAL alkaloid concentrations did not differ by location $(P=0.12)$ but differed $(P=0.001)$ by phenological stage (interaction $P=0.73$ ).

The proportion of the total MSAL alkaloid mix comprised of MLA differed by location $(P=0.004)$ and phenology $(P=0.04)$ with a significant interaction $(P=0.03)$. In Box Elder County and in Price, Utah, MLA was the dominant toxic alkaloid, although there were significant concentrations of 

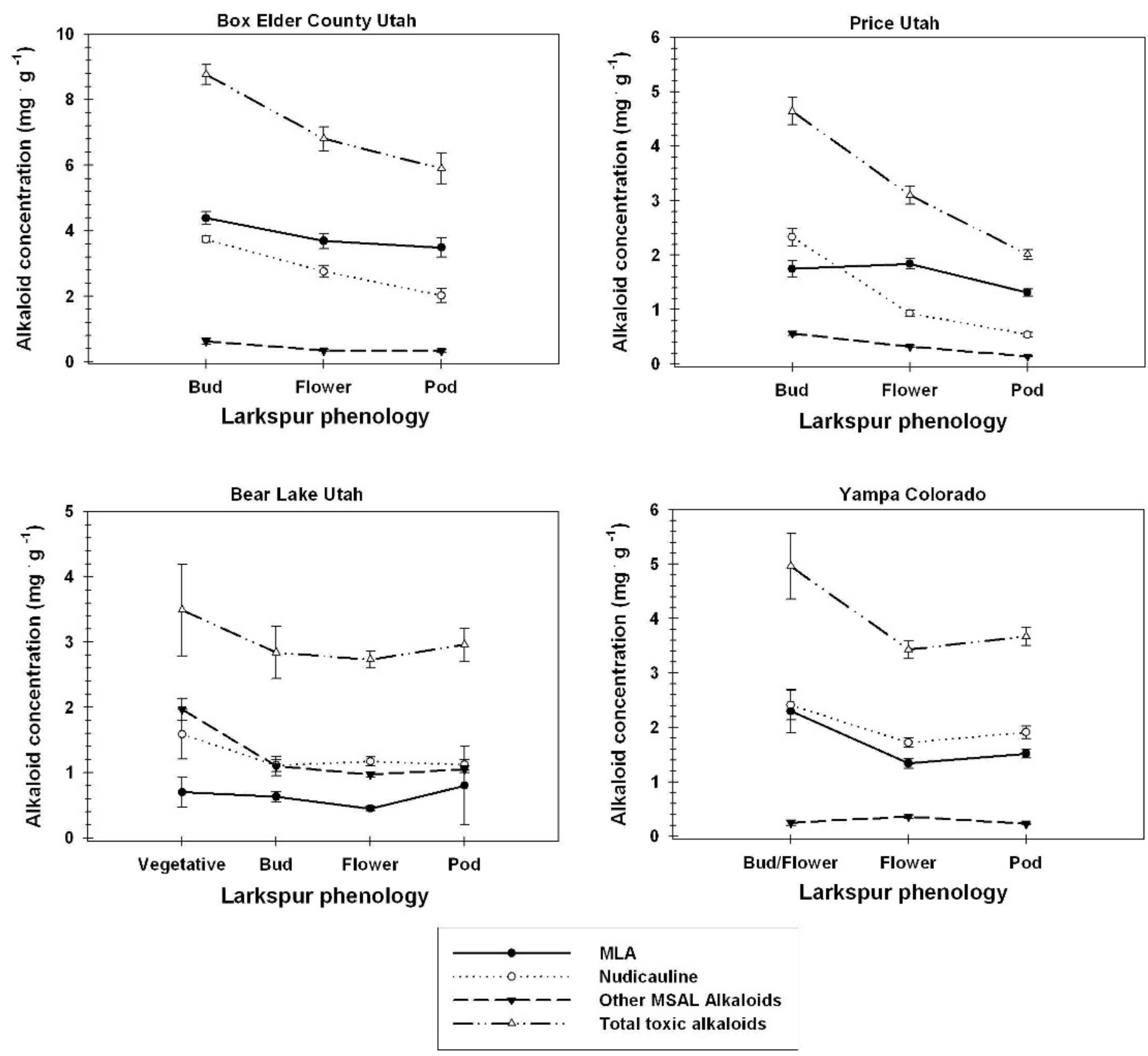

Figure 1. Concentration $\left(\mathrm{mg} \cdot \mathrm{g}^{-1} \mathrm{dry}\right.$ tissue $\pm \mathrm{SE}$ ) of methyllycaconitine $(\mathrm{MLA})$, nudicauline, other $\mathrm{N}$-(methylsuccinimido) anthranoyllycoctonine (MSAL) alkaloids, and total toxic alkaloids in low larkspur (Delphinium nuttallianum) in Utah and Colorado.

nudicauline. MLA made up $50 \%-60 \%$ of the total MSAL alkaloid fraction in Box Elder low larkspur plants, whereas MLA made up $37 \%-65 \%$ of the total fraction in larkspur plants from Price. MLA concentrations in plants from Box Elder equaled or exceeded $4 \mathrm{mg} \cdot \mathrm{g}^{-1}$ during all phenological growth stages. In contrast, MLA concentrations in low larkspur from Price peaked at about $2 \mathrm{mg} \cdot \mathrm{g}^{-1}$ (Fig. 1). MLA concentrations were relatively unchanged over time in both Box Elder and Price locations, with only small declines with maturation. Nudicauline concentrations decreased as plants matured at both of these locations. Nudicauline concentrations equaled or exceeded MLA concentrations in larkspur plants from Bear Lake, Utah, and Yampa, Colorado (Fig. 1). The concentration of other MSAL alkaloids from the Bear Lake, Utah, collection was similar to nudicauline. Low larkspurs had average dry matter concentrations from $15 \%$ to $54 \%$ across all collections.

\section{D. andersonii Alkaloid Concentration}

The concentration of geyerline was equal to or greater than MLA at each phenological stage (Fig. 2). The combined concentration of MLA and geyerline exceeded $4 \mathrm{mg} \cdot \mathrm{g}^{-1}$ during the vegetative stage and was approximately $3 \mathrm{mg} \cdot \mathrm{g}^{-1}$ during the flower stage of growth. MLA made up approximately $30 \%-40 \%$ of the total alkaloid (toxic and nontoxic) fraction. Total MSAL alkaloid concentrations closely mirrored the combined amounts of MLA and geyerline, as there were 


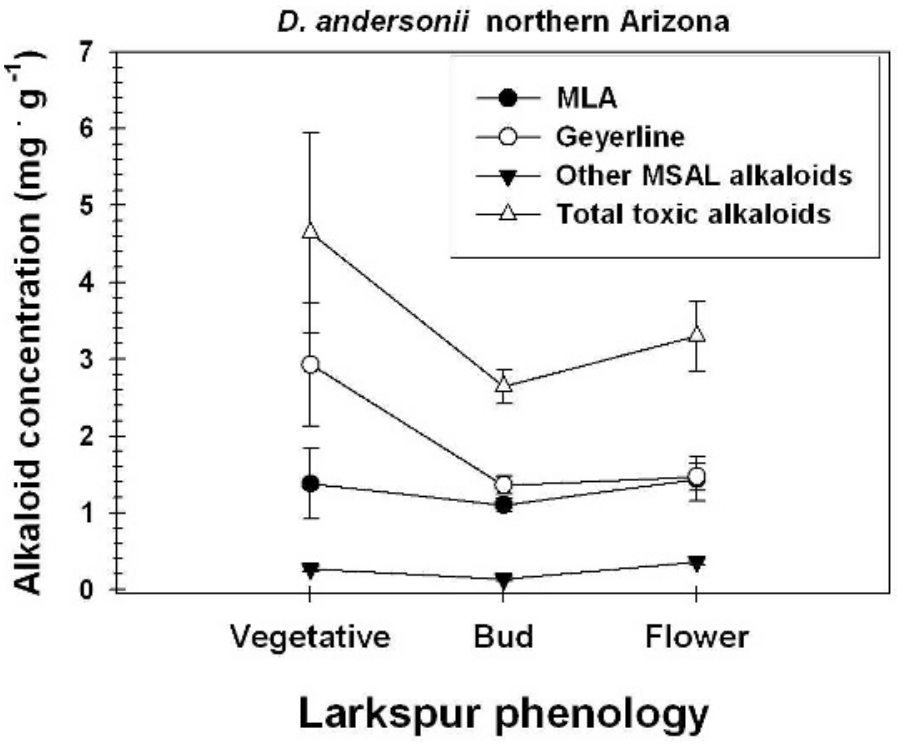

Figure 2. Concentration $\left(\mathrm{mg} \cdot \mathrm{g}^{-1}\right.$ dry tissue $\pm \mathrm{SE}$ ) of methyllycaconitine (MLA), geyerline, other $\mathrm{N}$-(methylsuccinimido) anthranoyllycoctonine (MSAL) alkaloids, and total toxic alkaloids in low larkspur (Delphinium andersonii) in northern Arizona.

only trace amounts of other alkaloids in these plants. The dry matter content of $D$. andersonii averaged $22 \%-27 \%$ across phenological stages.

\section{D. geyeri Alkaloid Concentration}

MSAL alkaloid concentrations were typically highest (2$4 \mathrm{mg} \cdot \mathrm{g}^{-1}$ ) in immature and mature (i.e., pod stage) plants (Fig. 3). Total alkaloid concentrations (i.e., toxic and less toxic alkaloids) were high in all locations and years, often exceeding $10 \mathrm{mg} \cdot \mathrm{g}^{-1}$ in immature larkspur (Fig. 3). MSAL alkaloids made up approximately $14 \%-24 \%$ of the total alkaloid fraction in D. geyeri. A drought during the summer of 1998 in Laramie, Wyoming, halted growth of plains larkspur, and no plants produced pods that year. Plains larkspur contained $21 \%-47 \%$ dry matter averaged over all samples.

\section{DISCUSSION}

Concentrations of toxic MSAL alkaloids in D. nuttalliunum, $D$. andersonii, and D. geyeri often did not decline during the growing season as typically found in tall larkspurs (i.e., Delphinium barbeyi [Huth] Welch and Delphinium occidentale [Wats.] Wats.; Pfister et al. 1994; Ralphs et al. 1997). MLA concentrations in $D$. andersonii from the Arizona Strip did not decline during the single season sampled. Similarly, MSAL alkaloid concentrations in plains larkspur showed no decline in 1997 and 1998, instead actually increasing slightly each year. Moreover, the MLA concentration in D. nuttallianum from 3 locations in Utah showed essentially no reduction during maturation. This study confirms earlier reports (Majak and Engelsjord 1988; Pfister and Gardner 1999) that MLA concentrations in low larkspur are relatively stable over time.

Total toxic MSAL alkaloid concentrations near or above $3 \mathrm{mg} \cdot \mathrm{g}^{-1}$ present a significant risk to grazing cattle if larkspurs are consumed in sufficient quantity (Pfister et al. 1997). The major toxic alkaloid in larkspurs is typically MLA, but in low larkspurs the concentration of other MSAL alkaloids is also important. The $\mathrm{LD}_{50}$ (median lethal dose) of MLA in mice is $4.5 \mathrm{mg} \cdot \mathrm{kg}^{-1}$ body weight (b.w.; intravenous dose; Manners et al. 1995), and the $\mathrm{LD}_{50}$ of geyerline is $6.2 \mathrm{mg} \cdot \mathrm{kg}^{-1}$ b.w. (Gardner et al. 2000). The $\mathrm{LD}_{50}$ for nudicauline is $2.7 \mathrm{mg} \cdot \mathrm{kg}^{-1}$ b.w. (Manners et al. 1995). Assuming that these levels of lethality also correspond to toxicity in cattle, the presence of nudicauline and other MSAL-type alkaloids in low larkspurs (D. nuttallianum) can greatly enhance the toxicity and risk to grazing cattle. Geyerline was the dominant toxic alkaloid in D. andersonii rather than MLA. This result again emphasizes the potential toxicity of $D$. andersonii or other low larkspurs when the plants contain other MSAL alkaloids in addition to MLA. Concentrations of nudicauline in $D$. nuttallianum and geyerline in D. andersonii declined slightly over the growing season. Majak and Engelsjord (1988) found substantial amounts of nudicauline in low larkspur, but they were not aware of the acute toxicity of nudicauline and thus did not measure seasonal changes.

We estimate that the $\mathrm{LD}_{50}$ of the toxic alkaloid fraction (MSAL alkaloids) from oral ingestion in cattle is about $30 \mathrm{mg} \cdot \mathrm{kg}^{-1}$ b.w. (Pfister et al. 1994). For grazing cattle this amounts to about $3.5 \mathrm{~kg}$ of dry larkspur containing about $4 \mathrm{mg} \cdot \mathrm{g}^{-1}$ of MSAL alkaloids. Dry weights varied considerably for individual flowering low and plains larkspur plants. Ranges were D. nuttalliunum, $0.25-1.3 \mathrm{~g} ; D$. andersonii, 0.30-2.3 g; and D. geyeri, 0.34-9.3 g (Pfister, unpublished data). A fatal dose of mature D. nuttallianum containing $4 \mathrm{mg} \cdot \mathrm{g}^{-1}$ toxic alkaloids would require consumption of at least 2500 plants within 2 or 3 days (Pfister et al. 1999). If cattle are physically stressed by movement, the threshold for a lethal dose may be substantially reduced (Pfister et al. 1999).

The concentration of MSAL alkaloids (i.e., MLA, nudicauline, geyerline) in low larkspurs differed between locations. Majak (1993) and Majak and Engelsjord (1988) also reported that concentrations of MLA in D. nuttallianum differed among locations and sites. Majak (1993) found that MLA concentrations in D. nuttallianum in western Canada averaged $3.7 \mathrm{mg} \cdot \mathrm{g}^{-1}$. Only in Box Elder County, Utah, did we find MLA concentrations that approached or exceeded this concentration. The ecological factors that drive diterpenoid alkaloid concentrations from region to region are poorly understood (Ralphs et al. 2000). Environmental differences, such as soil moisture, precipitation, and shade, have been thought to be major factors (Majak and Engelsjord 1988; Ralphs and Gardner 2001), but studies with tall larkspur (D. barbeyi) have not supported this idea (Ralphs et al. 1998, 2000). Majak and Engelsjord (1988) observed that MLA concentrations increased with elevation and suggested that this might be a result of increased precipitation. Alkaloid synthesis pathways are highly regulated and involve controls at the cell, tissue, plant, and environmental levels (Facchini 2001). Benn and May (1964) indicated that larkspur alkaloids are synthesized in roots, but little is known about further synthesis and translocation.

D. nuttalliunum, D. andersonii, and D. geyeri together are responsible for substantial but highly variable cattle losses across the western United States and Canada. Our past grazing 


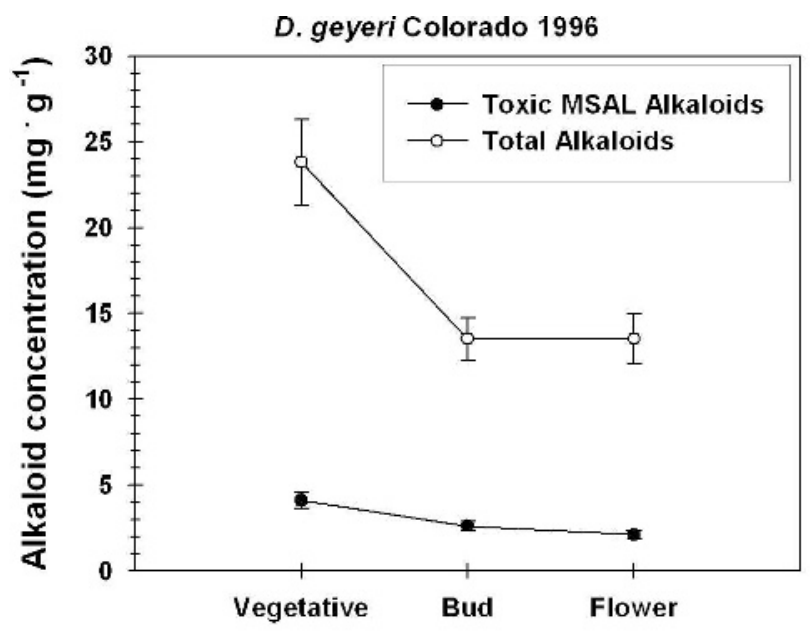

D. geyeri Cheyenne Wyoming 1996 \& 1997
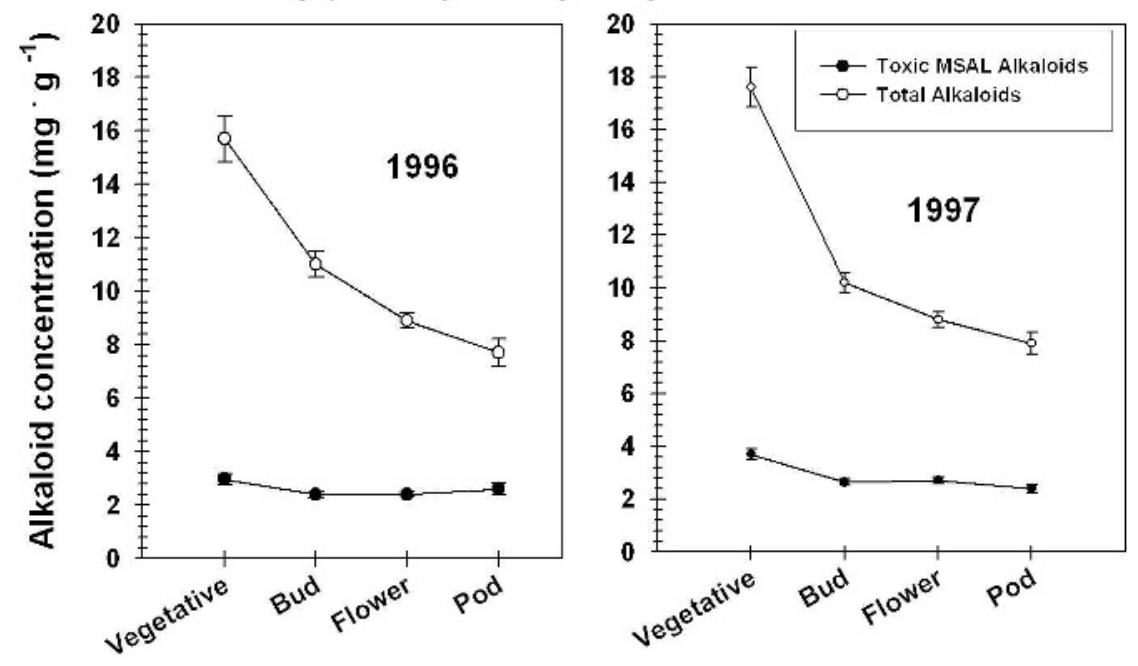

D. geyeri Laramie Wyoming 1998 \& 1999
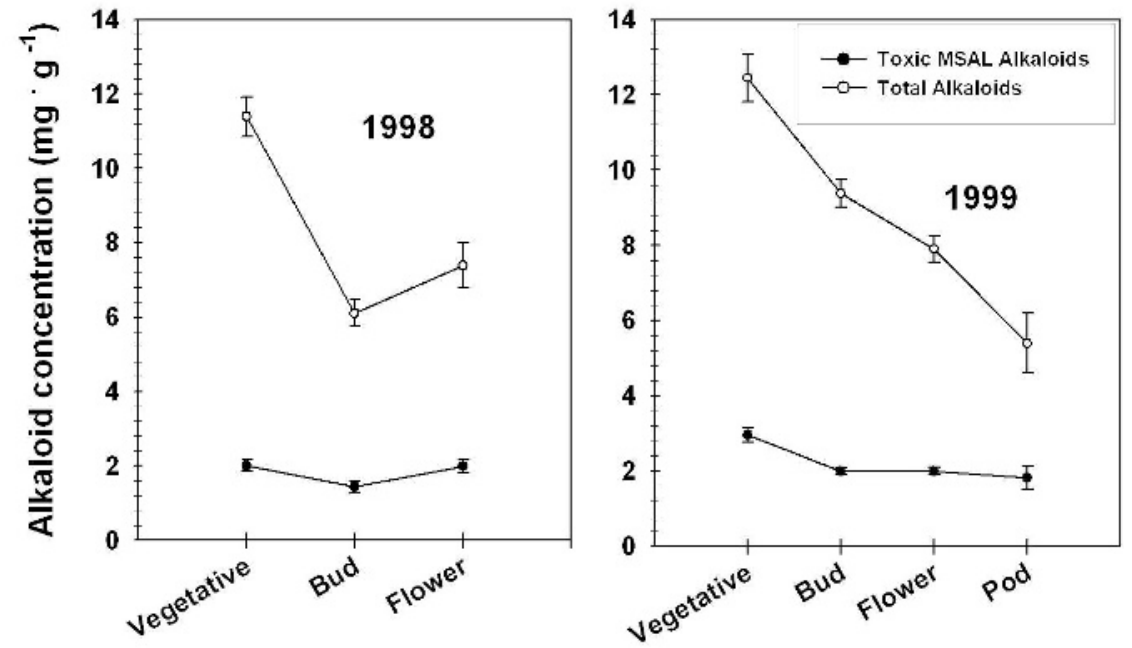

\section{Larkspur Phenology}

Figure 3. Concentration $\left(\mathrm{mg} \cdot \mathrm{g}^{-1}\right.$ dry tissue $\pm \mathrm{SE}$ ) of total $\mathrm{N}$-(methylsuccinimido) anthranoyllycoctonine (MSAL) alkaloids (primarily methyllycaconitine $[\mathrm{MLA}]$ and geyerline) and total alkaloids (toxic and less toxic) in plains larkspur (Delphinium geyeri) in Wyoming and Colorado. 
studies included D. nuttallianum (Pfister and Gardner 1999) and D. geyeri (Pfister et al. 2002), but few discernible grazing patterns emerged from studies with $D$. geyeri. We recommend that range and animal management to reduce losses to $D$. nuttallianum consider several interrelated factors, including concentration of toxic alkaloids, low larkspur density, forage availability, and the season of year. If the total toxic alkaloid concentration of representative low larkspur samples is lower than the $3-\mathrm{mg} \cdot \mathrm{g}^{-1}$ threshold, risk is relatively low, and grazing may not need to be restricted if sufficient other forage is available. If low larkspur toxicity exceeds $3 \mathrm{mg} \cdot \mathrm{g}^{-1}$, the density of low larkspur and the abundance of other available forage must be carefully considered in any grazing management scheme. These factors will greatly impact the rate and amount of low larkspur cattle are able to consume. The density of low larkspur is typically higher when winter snowpack is above normal and ambient temperatures are below normal (Saavedra et al. 2003; Pfister, unpublished observations). Our grazing studies suggest that widespread low larkspur densities of $>5$ plants $\cdot \mathrm{m}^{-2}$ increase the availability of low larkspur and the risk of cattle grazing the plant (Pfister and Gardner 1999). Further, low larkspur plants are typically problematic on rangelands during spring and early summer, but after low larkspur matures and pods shatter, the availability of toxic low larkspur decreases greatly, and the concomitant increase in biomass of other palatable forage will further reduce the risk for grazing cattle.

\section{MANAGEMENT IMPLICATIONS}

Alkaloid concentrations in low and plains larkspur determine the potential toxicity to cattle, in conjunction with the amount and rate of larkspur consumption. Concentrations of toxic alkaloids may not decline with plant maturity, thus maintaining substantial risk to grazing cattle until plants are dormant. Livestock producers with rangelands that have populations of low and plains larkspurs must be able to identify these plants, recognize those years when Delphinium density is high in spring or summer, and then adjust cattle management to reduce risk of losses.

\section{ACKNOWLEDGMENTS}

We thank Kermit Price and Scott Larsen for technical assistance with the research.

\section{LITERATURE CITED}

Benn, M. H., And J. May. 1964. The biosynthesis of diterpenoid alkaloids. Experientia 29:252-253.

FACCHINI, P. J. 2001. Alkaloid biosysnthesis in plants: biochemistry, cell biology, molecular regulation, and metabolic engineering applications. Annual Review of Plant Physiology and Plant Molecular Biology 52:29-66.
Gardner, D. R., G. D. Manners, K. E. Panter, S. T. Lee, and J. A. Pfister. 2000. Three new toxic norditerpenoid alkaloids from the low larkspur Delphinium nuttallianum. Journal of Natural Products 63:1127-1130.

Gardner, D. R., G. D. Manners, M. H. Ralphs, and J. A. Pfister. 1997. Quantitative analysis of norditerpenoid alkaloids in larkspur (Delphinium spp.) by Fourier transform infrared spectroscopy. Phytochemical Analysis 8:55-62.

Gardner, D. R., K. E. Panter, J. A. Pfister, and A. P. Knight. 1999. Analysis of toxic norditerpenoid alkaloids in Delphinium species by electrospray, atmospheric pressure chemical ionization, and sequential tandem mass spectroscopy. Journal of Agriculture and Food Chemistry 47:5049-5058.

MAJAK, W. 1993. Alkaloid levels in a species of low larkspur and their stability in rumen fluid. Journal of Range Management 46:100-104.

Majak, W., And M. Engelsjord. 1988. Levels of a neurotoxic alkaloid in a species of low larkspur. Journal of Range Management 41:224-226.

Manners, G. D., K. E. Panter, and S. W. Pelletier. 1995. Structure-activity relationships of norditerpenoid alkaloids occurring in toxic larkspur (Delphinium) species. Journal of Natural Products 58:863-869.

Manners, G. D., K. E. Panter, J. A. Pfister, M. H. Ralphs, and L. F. James. 1998. The characterization and structure-activity evaluation of toxic norditerpenoid alkaloids from two Delphinium species. Journal of Natural Products 61:1086-1089.

Marsh, C. D., A. B. Clawson, and H. Marsh. 1916. Larkspur poisoning of live stock. USDA Bureau of Animal Industry Bulletin 365.

Pfister, J. A., and D. R. Gardner. 1999. Consumption of low larkspur (Delphinium nuttallianum) by cattle. Journal of Range Management 52:378-383.

Pfister, J. A., D. R. Gardner, K. E. Panter, M. H. Ralphs, G. D. Manners, B. L. Stegelmeler, and T. K. Schoch. 1999. Larkspur (Delphinium spp.) toxicity to livestock. Journal of Natural Toxins 8:81-94.

Pfister, J. A., D. R. Gardner, B. L. Stegelmeier, K. Hackett, and G. Secrist. 2003. Catastrophic cattle loss to low larkspur (Delphinium nuttallianum) in Idaho. Veterinary and Human Toxicology 45:137-139.

Pfister, J. A., D. R. Gardner, B. L. Stegelmeier, A. P. Knight, J. W. Waggoner, JR., and J. 0. Hall. 2002. Plains larkspur (Delphinium geyeri) grazing by cattle in Wyoming. Journal of Range Management 55:350-359.

Pfister, J. A., K. E. Panter, and G. D. Manners. 1994. Effective dose in cattle of toxic alkaloids from tall larkspur (Delphinium barbeyi). Veterinary and Human Toxicology 36:10-11.

Pfister, J. A., M. H. Ralphs, G. D. Manners, D. R. Gardner, K. W. Price, and L. F. James. 1997. Early season grazing of tall larkspur- (Delphinium spp.) infested rangeland. Journal of Range Management 50:391-398.

Ralphs, M. H., and D. R. Gardner. 2001. Alkaloid levels in duncecap (Delphinium occidentale) and tall larkspur (D. barbeyi) grown in reciprocal gardens: separating genetic from environmental influences. Biochemical Systematics and Ecology 29:117-124.

Ralphs, M. H., D. R. Gardner, and J. A. Pfister. 2000. A functional explanation for patterns of norditerpenoid alkaloid levels in tall larkspur (Delphinium barbeyi). Journal of Chemical Ecology 26:1595-1607.

Ralphs, M. H., G. D. Manners, and D. R. Gardner. 1998. Influence of light and photosynthesis on alkaloid concentration in larkspur. Journal of Chemical Ecology 24:167-182.

Ralphs, M. H., G. D. Manners, J. A. Pfister, D. R. Gardner, and L. F. James. 1997. Toxic alkaloid concentration in tall larkspur species in the western U.S. Journal of Range Management 50:497-502.

Saavedra, F., D. W. Inouye, M. V. Price, and J. Harte. 2003. Changes in flowering and abundance of Delphinium nuttallianum (Ranunculaceae) in response to a subalpine climate warming experiment. Global Change Biology 9:885-894.

SAS InstituTE. 2002. Statistical Analysis System for Windows. Version 9.1. Cary, NC: SAS Institute. 